
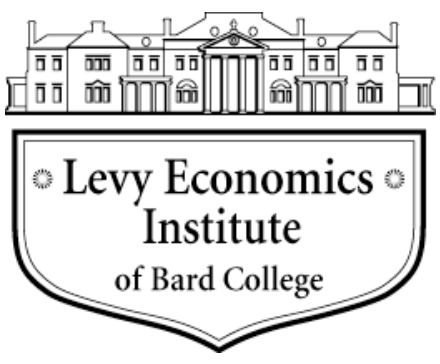

Working Paper No. 792

\title{
From the State Theory of Money to Modern Money Theory: An Alternative to Economic Orthodoxy
}

by

\author{
L. Randall Wray* \\ Levy Economics Institute of Bard College
}

March 2014

* I thank participants of a workshop held at Cambridge University and especially Geoff Ingham, who provided insightful comments on an earlier draft of this paper.

This paper was prepared for the project "Financing Innovation: An Application of a Keynes-SchumpeterMinsky Synthesis," funded in part by the Institute for New Economic Thinking, INET grant no. IN012-00036, administered through the Levy Economics Institute of Bard College. Co-principal investigators: Mariana Mazzucato (Science Policy Research Unit, University of Sussex) and L. Randall Wray (Levy Institute). The author thanks INET and the Levy Institute for support of this research.

The Levy Economics Institute Working Paper Collection presents research in progress by Levy Institute scholars and conference participants. The purpose of the series is to disseminate ideas to and elicit comments from academics and professionals.

Levy Economics Institute of Bard College, founded in 1986, is a nonprofit, nonpartisan, independently funded research organization devoted to public service. Through scholarship and economic research it generates viable, effective public policy responses to important economic problems that profoundly affect the quality of life in the United States and abroad.

Levy Economics Institute

P.O. Box 5000

Annandale-on-Hudson, NY 12504-5000

http://www.levyinstitute.org

Copyright (C) Levy Economics Institute 2014 All rights reserved 


\begin{abstract}
This paper explores the intellectual history of the state, or chartalist, approach to money, from the early developers (Georg Friedrich Knapp and A. Mitchell Innes) through Joseph Schumpeter, John Maynard Keynes, and Abba Lerner, and on to modern exponents Hyman Minsky, Charles Goodhart, and Geoffrey Ingham. This literature became the foundation for Modern Money Theory (MMT). In the MMT approach, the state (or any other authority able to impose an obligation) imposes a liability in the form of a generalized, social, legal unit of account — a money — used for measuring the obligation. This approach does not require the preexistence of markets; indeed, it almost certainly predates them. Once the authorities can levy such obligations, they can name what fulfills any obligation by denominating those things that can be delivered; in other words, by pricing them. MMT thus links obligatory payments like taxes to the money of account as well as the currency. This leads to a revised view of money and sovereign finance. The paper concludes with an analysis of the policy options available to a modern government that issues its own currency.
\end{abstract}

Keywords: Modern Money Theory; Chartalism; State Money; Knapp; Innes; Schumpeter; Keynes; Minsky; Goodhart; Ingham; Sovereign Currency

JEL Classifications: B1, B3, B15, B22, B25, B52, E40, E50, E62, H5, H60, N1 


\section{INTRODUCTION}

In this working paper I will examine the intellectual history of an alternative to the orthodox approach to money and credit. Charles Goodhart has usefully distinguished between what he called the orthodox "Metalist" and the heterodox "Chartalist" approaches. The first focuses on money as a medium of exchange, which in the past derived its value through a link to precious metal. This is not meant to imply orthodoxy excludes the other functions of money, or to claim that modern orthodox economists would want to return to a gold standard. Rather, the focus on money's metallic origins as a cost-minimizing medium of exchange frames thinking about the nature of money.

Many orthodox policy prescriptions follow fairly directly from this vision, in particular the view that money's value is linked to its scarcity. The advantage of the gold standard was precisely the imposed scarcity, while the problem with fiat money is that it can be "dropped by helicopters," as in Friedman's famous analogy. Hence in the absence of linking money to gold, we must find another way to constrain its supply so that the money supply just matches demand at a stable price.

The second approach is much more consistent with the legal view of money. It could be said that "money is a creature of law" with emphasis on the link between money and contracts; for example, whatever is defined as legal money can be delivered to settle contracts. ${ }^{2}$ Legal tender laws normally require that the State's own currency must be accepted. Hence, it highlights the important role played by "authorities" in the origins and evolution of money. In the Chartalist approach, the State (or any other authority able to impose an obligation) imposes a liability in the form of a generalized, social or legal unit of account - a money-used for measuring the obligation. This does not require the pre-existence of markets, and, indeed, almost certainly predates them. Once the authorities can levy such obligations, they can name what fulfills this obligation by denominating those things that can be delivered, in other words, by pricing them. This resolves the conundrum faced by methodological individualists and emphasizes the social nature of money and markets - which did not spring from the minds of individual utility maximizers to replace barter, but rather were socially created.

2 Geoff Ingham reminds me that this is especially true of those who follow F. W. Mann (1982 [1938]) The Legal Aspect of Money, Oxford: Clarendon Press 
This paper will not address further the orthodox, Metalist approach in detail. Nor will it attempt to demonstrate that the Chartalist approach is more consistent with the historical factsas we know them. Finally, this paper will not present a rigorous history of thought. Instead, it will focus only on a handful of major figures whose work was important in building a modern version of Chartalism, an approach now called Modern Money Theory (MMT). The main contributors to the Chartalist tradition were Knapp, Innes, Keynes, Lerner, and Minsky, and more recently Goodhart and Ingham. This chapter will not attempt to examine the influences on each of these but rather will identify their contributions that influenced the development of MMT.

In recent years, MMT has risen to prominence, especially on the Internet, largely for two reasons. First, its understanding of the nature of money leads to interesting policy conclusions. Second, and related to that, MMT provides a description of modern fiscal and policy operations that is quite different from orthodox economics. Indeed, it is this alternative exposition that leads quite directly to the different approach to policy-making. We first examine the early contributions of Knapp, Innes and Keynes while including a brief summary of Schumpeter's views on money and credit. We then move to the more recent contributions in this tradition, focusing on those of Minsky, Lerner, and Ingham. This chapter will conclude with a brief examination of related policy issues. 


\section{STATE MONEY, CREDIT MONEY AND CHARTALISM: THE CONTRIBUTIONS OF KNAPP, INNES, KEYNES, AND SCHUMPETER}

\subsection{Knapp}

Georg Friedrich Knapp developed the state theory of money, an approach that is directly opposed to the Metalist view, according to which the value of money derives from the value of the metal standard (for example, gold or silver) adopted. More generally, according to Knapp, metalists try to "deduce" the monetary system "without the idea of a State." This, he believes, is "absurd," for "the money of a state" is that which is "accepted at the public pay offices" (Knapp [1924] 1973, pp. vii-viii; see also Goodhart, 1989). Knapp's exposition is quite complex and required the creation of a classificatory scheme with dozens of idiosyncratic terms. We will try to keep our summary simple; to some extent we will have to paraphrase rather than use extensive quotes, for otherwise we would have to define the numerous terms he coined. This section will be the longest and most detailed as Knapp's exposition serves as the basis for the Chartalist approach to State money and also to private credit monies.

According to Knapp, debts are expressed in a unit of value — "the unit in which the amount of the payment is expressed" (Ibid., 8) and discharged with means of payment; "a movable thing which has the legal property of being the bearer of units of value" (Ibid., 7). What, then, determines which things will act as means of payment to discharge debts? Knapp recognized that means of payment are occasionally changed; sometimes one type of material (say, weighed or coined gold) has been accepted but "suddenly" another (say, weighed or coined silver) takes its place. Therefore, while the means of payment may be a definite material, it is not bound to any particular material, for it may be changed (Ibid., 8-25). "A proclamation is made that a piece of such and such a description shall be valid as so many units of value" (Ibid., 30). "Validity by proclamation is not bound to any material. It can occur with the most precious or the basest metals ..." (Ibid., 30). The fundamental insight was his recognition that these transitions always require that the state announce a conversion rate (say, so many ounces of gold for so many ounces of silver). Hence, the debts were always nominal and were never actually "metallic": all debts are converted to the new metal, which proves that all units of account must be nominal. 
Knapp described the modern monetary system, where Chartal money has developed:

When we give up our coats in the cloak-room of a theatre, we receive a tin disc of a given size bearing a sign, perhaps a number. There is nothing more on it, but this ticket or mark has legal significance; it is a proof that I am entitled to demand the return of my coat. When we send letters, we affix a stamp or a ticket which proves that we have by payment of postage obtained the right to get the letter carried. The "ticket" is then a good expression ... for a movable, shaped object bearing signs, to which legal ordinance gives a use independent of its material. Our means of payment, then, whether coins or warrants, possess the above-named qualities: they are pay-tokens, or tickets used as means of payment... Perhaps the Latin word "Charta" can bear the sense of ticket or token, and we can form a new but intelligible adjective - "Chartal." Our means of payment have this token, or Chartal, form. Among civilized peoples in our day, payments can only be made with pay-tickets or Chartal pieces. (Knapp [1924] 1973, pp. 31-2)

Note that like the tin disc issued by the cloakroom, the material used to manufacture the Chartal pieces is wholly irrelevant - it can be gold, silver or common metal; it can be paper and today, it can be electronic entries on tape or hard-drive.

It is, therefore, impossible to tell from the pieces themselves whether they are Chartal or not. This is at once evident in the case of warrants. As to coins, we must always refer to the Acts and Statutes, which alone can give information ... if the pieces gain their validity through proclamation, they are Chartal. (Ibid., 34-5)

Finally, "Money always signifies a Chartal means of payment. Every means of payment we call money. The definition of money is therefore a Chartal means of payment" (Ibid., 34-8).

Chartalism is often identified with the proposition that legal tender laws determine that which must be accepted as means of payment (following Schumpeter's interpretation of Knapp). However, Knapp's analysis went further.

If we have already declared in the beginning that money is a creation of law, this is not to be interpreted in the narrower sense that it is a creation of jurisprudence, but in the larger sense that it is a creation of the legislative activity of the State, a creation of legislative policy. (Ibid., 40)

And what is the nature of this "legislative activity" that determines what will be the Chartalist money accepted within the jurisdiction of the state? 
What forms part of the monetary system of the State and what does not? We must not make our definition too narrow. The criterion cannot be that the money is issued by the State, for that would exclude kinds of money which are of the highest importance; I refer to bank-notes: they are not issued by the State, but they form a part of its monetary system. Nor can legal tender be taken as the test, for in monetary systems there are very frequently kinds of money which are not legal tender... We keep most closely to the facts if we take as our test, that the money is accepted in payments made to the State's offices. Then all means by which a payment can be made to the State form part of the monetary system. On this basis it is not the issue, but the acceptation, as we call it, which is decisive. State acceptation delimits the monetary system. By the expression "State-acceptation" is to be understood only the acceptance at State pay offices where the State is the recipient. (Ibid., 95)

It is the decision of the state to accept at state pay offices, and not legal tender laws, that creates a Chartal money.

In the monetary system of a State there must be one kind of money which is definitive, as opposed to provisional (convertible) money... Money is definitive if, when payment is made in it, the business is completely concluded... The payer is no longer under an obligation, the recipient has no further rights either against the payer or against the State, if the State has issued the money [Ibid., 102] ... ( p. 105).

It is not simply a "legal tender" law that makes state notes acceptable in private transactions, but it is the fact that the state first decides what it will use or accept as money in its own transactions, and that this must then be acceptable as means of settlement of private debts. "The laws do not decide what shall be valuta money, ${ }^{3}$ they merely express a pious hope, for they are powerless against their creator, the State ..." (Ibid., 111).

Knapp extended his analysis to include bank money. "The bank makes notes and offers them in payment to its customers. Issuing notes is not a special business . . but a special way in which the bank endeavours to make its payments .... It tries to pay in its own notes instead of in money issued by the State, because then with a comparatively small capital it can make greater profits than it otherwise could" (Ibid., 131). Acceptability of banknotes in private transactions is not (as was commonly believed) due to the bank promise to convert these to specie. In other words, bank money did not derive its value from the gold reserves or specie coin into which it promised redemption. Whether banknotes are convertible is irrelevant: "An

\footnotetext{
3 Knapp defines definitive money as that which the state will accept at pay offices, while valuta money is a component of definitive money, namely that which the state will provide in its own payments.
} 
inconvertible bank-note, then, is not a nullity, but has this in common with the convertible banknote, that it is a till-warrant of the bank" (op cit. p. 134). What is important is that the note "is a private till-warrant available for payments to the bank . . but clearly the customers of the bank can use it for payments between themselves, as they are sure it will be taken at the bank. These customers and the bank form, so to speak, a private pay community; the public pay community is the State" (Ibid.).

Knapp argues that banknotes do not derive their value from the reserves (whether gold or government fiat money) held for conversion, but rather from their use in the "private pay community" and "public pay community"; this, in turn, is a function of "acceptation" at the bank and public pay offices. Within the "private pay community" (or "giro"), bank money is the primary money used in payments; however, payments in the "public pay community" require state money. This can include bank money, but note that generally, delivery of bank money to the state is not final, or definitive, because the state will present it to banks for "redemption" (for valuta reserves). Bank money, when used in the public pay community is not "definitive" unless the state also uses it in its own purchases.

What can make banknotes state money? "Bank-notes are not automatically money of the state, but they become so as soon as the State announces that it will receive them in epicentric payments [payments to the state]" (Knapp [1924] 1973, p. 135). If the state accepts notes in payment to the state, then the banknotes become "accessory" and the business of the bank is enhanced, "for now everybody is glad to take its bank-notes since all inhabitants of the State have occasion to make epicentric payments (e.g. for taxes)" (Ibid., 137). The banknotes then become "valuta" money if the state takes the next step and makes "apocentric payments [payments by the State] in bank-notes" (Ibid., 138). However, states often required that banks make their notes convertible to state-issued money: "one of the measures by means of which the State assures a superior position to the money which it issues itself” (Ibid., 140), and thus maintained banknotes in the role of accessory money (rather than allowing them to become valuta money). If the state accepts banknotes in payment, but does not make payments in these banknotes, then the notes will be redeemed - leading to a drain of "reserves" (indeed, governments and central banks used redemption or threat of redemption to "discipline" banks).

In times of distress, however, governments would pass laws ending convertibility, announce that the state would henceforth make payments in terms of the banknotes, and thereby declare that the banknotes were valuta money (Knapp [1924] 1973, p. 143). Sometimes this was 
for one bank only - the bank which became the central bank. Through action of the state, then, paper money can become valuta money. "At first bank-notes and Treasury notes are employed only as accessory money ... The mournful hour arrives when the State has to announce that it can no longer pay in the money that was till then valuta [say, coined gold] and that those warrants themselves are now valuta" (Ibid., 196). ${ }^{4}$

At this point we have a Chartalist, non-convertible, paper money_often called "fiat money," as do modern developed countries. Of course, this extreme development came nearly three-quarters of a century after Knapp's book was first published (1905)—when we finally abandoned Bretton Woods. However, he had recognized that the money of a state does not derive its value from metal, and indeed, that no metal is needed domestically. He did argue, on the other hand, that in the international sphere, "To dispense with specie money altogether would only be possible for very large federations of States [and, therefore, is] probably impracticable. On account of foreign trade specie money is still necessary" (Ibid., xv). Within a state, however, specie is not necessary, for "state money may be recognized by the fact that it is accepted in payment by the State"; as Keynes said (see below), the state not only enforces the dictionary (legal tender laws) but writes it (decides what is to be accepted as money). ${ }^{5}$

We might, then, see the development of the gold standard as a solution to the problem of what to use for an international-stateless - money. The problem is that tying a domestic currency to gold created problems of internal monetary stability even as it resolved the problem of the need for an international money. As it happened, however, neither the gold standard, nor the Bretton Woods standard was sustainable because internal instability generates external instability.

Most paper money (today, mostly deposits) is privately issued and derives its demand not from a promise of redeemability but rather from state acceptance at pay offices. Knapp goes further, for he argues that the state eventually realizes (usually during a crisis) that it can also make payments in that which it promises to accept. Once freed from domestic convertibility on

4 This often comes after the bank has purchased government debt and issued notes that promised conversion; in times of war or other distress, the government would "encourage" banks to issue far more notes (to "finance" government spending) than they could conceivably convert. Thus suspension of convertibility served the interests of government as well as the bank.

5 Of course, the type of monetary system envisioned by Knapp is similar to the one adopted shortly thereafter by the US: a "gold standard" without domestic convertibility, but with a specie reserve to satisfy international purposes. Knapp did not foresee the time when metals could be dropped altogether in favour of foreign currency reserves and flexible exchange rates. 
a metallic standard, the state's spending domestically would not be constrained by the quantity of the metal available. Abandonment of the metallic standard internationally would eliminate metallic constraints on countries. The state thus moved to a paper money system domestically, making its apocentric payments in central bank notes and accepting epicentric payments in private bank notes (today, deposits) that would have to be redeemed (today, cleared) for the valuta central bank notes (today, reserves). Precious metals were then used only for international purposes until the US finally abandoned the gold standard altogether in the early 1970s.

In this chapter we won't address further the international currency regimes. Such discussion necessarily takes us beyond state money because sovereign government cannot generally use its sovereign power to impose liabilities in foreign nations. We next turn to Innes.

\subsection{Innes}

A. Mitchell Innes $(1913,1914,1932)$ suggested that we can locate the origins of credit and debt relations in the elaborate system of tribal wergild designed to prevent blood feuds. (See also Ingham 2004a,b, 2013a; Grierson 1977, 1979; and Goodhart 1998) Wergild fines were paid by transgressors directly to victims and their families, and were established and levied by public assemblies. A long list of fines for each possible transgression was developed, and a designated "rememberer" would be responsible for passing it down to the next generation. Note that each fine was levied in terms of a particular good that was both useful to the victim and more-or-less easily obtained by the perpetrator.

Innes believed that money evolves not from a pre-money market system but rather from the "penal system" based on the ancient practice of wergild. ${ }^{6}$ (Ingham 2004b; Wray 1998) Hence, he highlights the important role played by "authorities" in the origins and evolution of money. More specifically, the state (or any other authority able to impose an obligation) imposes a liability in the form of a generalized, social unit of account - a money - used for measuring the obligation. This does not require the pre-existence of markets, and, indeed, almost certainly predates them. Once the authorities can levy such obligations, they can name what fulfills this obligation by denominating those things that can be delivered, in other words,

6 As the great numismatist Philip Grierson put it: "The conditions under which these laws were put together would appear to satisfy much better than the market mechanism, the prerequisites for the establishment of a monetary system. The tariffs for damages were established in public assemblies, and $\cdots$ Since what is laid down consists of evaluations of injuries, not evaluation of commodities, the conceptual difficulty for appraising unrelated objects is avoided” (Grierson 1977: 20-21; quoted in Ingham 2013b. p. 124). 
by pricing them. This resolves the conundrum faced by methodological individualists and emphasizes the social nature of money and markets - which did not spring from the minds of individual utility maximizers, but rather were socially created. ${ }^{7}$

The state chooses the unit, names the thing accepted in payment of obligations to itself, and (eventually) issues the money-thing it accepts. The material from which the money thing issued by the state is produced is not important (whether it is gold, base metal, paper, or, now, even digitized numbers at the central bank). No matter what it is made of, the state must announce its nominal value (that is to say, the value at which the money-thing is accepted in meeting obligations to the state) and accept it in payments made to the state.

What is most interesting about the contributions of Innes is that he integrated the state theory of money with a credit theory of money. Along the lines of the latter, Schumpeter made a famous distinction between the "monetary theory of credit" and the "credit theory of money". The first sees private "credit money" as only a temporary substitute for "real money"- possibly a "natural" money that is free of social relations. Final settlement must take place in real money, which is the ultimate unit of account, store of value, and means of payment. Exchanges might take place based on credit, but credit expansion is strictly constrained by the quantity of real money. Ultimately, only the quantity of real money matters so far as economic activity is concerned. Most modern macroeconomic theory is based on the concept of a deposit multiplier that links the quantity of privately created money (mostly, bank deposits) to the quantity of high-powered money (HPM). This is the modern equivalent to what Schumpeter called the monetary theory of credit, and Friedman (or Karl Brunner) is the best representative. The real money that is the basis of deposit expansion should be controlled, preferably by a rule that will make the modern fiat money operate more like the metallic money of the hypothesized past.

The credit theory of money, by contrast, emphasizes that credit normally expands to allow economic activity to grow. This new credit creates new claims on HPM even as it leads to new production. However, because there is a clearing system that cancels claims and debits without use of HPM, credit is not merely a temporary substitute for HPM. Schumpeter does not deny the role played by HPM as an ultimate means of settlement; he simply denies that it is required for most final settlements.

7 See Hudson (2004) for a description of price setting by authorities in the early granary empires of Mesopotamia; and Polanyi (1971) for the role of authorities in setting up markets and negotiating prices across borders; and Ingham 2004a,b for related summaries. 
Like Schumpeter, Innes focused on credit and the clearing system, mocking the view that "in modern days a money-saving device has been introduced called credit and that, before this device was known all purchases were paid for in cash, in other words in coins." (Innes 1913, p. 389) Instead, he argued, "careful investigation shows that the precise reverse is true." (Innes 1913, p. 389) Rather than selling in exchange for "some intermediate commodity called the "medium of exchange," a sale is really "the exchange of a commodity for a credit." Innes called this the "primitive law of commerce": "The constant creation of credits and debts, and their extinction by being cancelled against one another, forms the whole mechanism of commerce..." (Innes 1913, p. 393) Innes explains:

By buying we become debtors and by selling we become creditors, and being all both buyers and sellers we are all debtors and creditors. As debtor we can compel our creditor to cancel our obligation to him by handing to him his own acknowledgment [sic] of a debt to an equivalent amount which he, in his turn, has incurred. (Innes 1913, p. 393)

The market, then, is not viewed as the place where goods are exchanged, but rather as a clearing house for debts and credits. Indeed, Innes rejected the typical analysis of the medieval village fairs, arguing that these were first developed to settle debts, with retail trade later developing as a sideline to the clearing house trade. On this view, debts and credits and clearing are the general phenomena; trade in goods and services is subsidiary-one of the ways in which one becomes a debtor or creditor (or clears debts). Innes viewed the creditor-debtor relation as the fundamental social relation lying behind money's veil. There is no "natural" relation-free money that lies behind the credit money. Indeed, for Innes even HPM is credit money — for reasons discussed in the next section.

The credit approach as advanced by Innes and Schumpeter provides a more useful vision of monetary operations of a capitalist, "market", economy than does the orthodox vision of money serving as a lubricating medium of exchange. The monetary production economy as described by Marx, Veblen, and Keynes is dominated by a complex web of financial relations that were characterized by Minsky as "money now for money later” propositions. (Minsky 1986 p. 228) Money is not a veil that should be stripped away to observe the essential characteristics of the "market economy." Rather, the money of account and those credit-debt relations are the key institutional relations of the capitalist economy. 
Innes sounds very much like Knapp on the state's money, although there is no direct indication that he was drawing on Knapp's exposition. However, Innes is best on generalizing the credit approach to money to include the state's own currency as a credit money. He insisted that when the state spends, it becomes a debtor (as he said, "by buying we become debtors") as it issues state money. Hence, even state money is credit money, however, it is a special kind of credit, "redeemed by taxation". (1914, p. 168) For the government, a dollar is a promise to "pay," a promise to "satisfy," a promise to "redeem," just as all other money is. Innes argued that even on a gold standard it is not gold that government promises to pay: It is true that all the government paper money is convertible into gold coin, "but redemption of paper issues in gold coin is not redemption at all, but merely the exchange of one form of obligation for another of an identical nature.” (Innes 1914, p. 165)

Whether the government's IOU is printed on paper or on a gold coin, it is indebted just the same. What, then, is the nature of the government's IOU? Innes identifies the "very nature of credit throughout the world," which is "the right of the holder of the credit (the creditor) to hand back to the issuer of the debt (the debtor) the latter's acknowledgment or obligation." (1914, p. 161) The holder of a coin or certificate has the absolute right to pay any debt due to the government by tendering that coin or certificate, and it is this right and nothing else which gives them their value. It is immaterial whether or not the right is conveyed by statute, or even whether there may be a statute law defining the nature of a coin or certificate otherwise. (1914, p. 161)

Hence, we can integrate the state money and credit money approaches through the recognition of the "very nature of credit," which is that the issuer must accept its own IOUs. What, then, is special about government? The government's credit "usually ranks in any given city slightly higher than does the money of a banker outside the city, not at all because it represents gold, but merely because the financial operations of the government are so extensive that government money is required everywhere for the discharge of taxes or other obligations to the government." (Innes 1914, p. 154) The special characteristic of government money, then, is that it is "redeemable by the mechanism of taxation" (Innes 1914, p. 15): "[I]t is the tax which imparts to the obligation its 'value'.... A dollar of money is a dollar, not because of the material of which it is made, but because of the dollar of tax which is imposed to redeem it." (Innes 1914, p. 152) 
In spite of the attention paid to the gold standard, it was actually in place for only a short period. Typically, the money-thing issued by the authorities was not gold-money nor was there any promise to convert the money-thing to gold. Indeed, as Innes insisted, throughout most of Europe's history, the money-thing issued by the state was the hazelwood tally stick: "This is well seen in medieval England, where the regular method used by the government for paying a creditor was by 'raising a tally' on the Customs or on some other revenue getting department, that is to say by giving to the creditor as an acknowledment of indebtedness a wooden tally." (Innes 1913, p. 398; see also Robert 1956 and Maddox 1969) Other money-things included clay tablets, leather and base metal coins, and paper certificates. ${ }^{8}$

Why would the population accept otherwise "worthless" sticks, clay, base metal, leather, or paper? Because these were evidence of the State's liabilities that it would accept in payment of taxes and other debts owed to itself. The key power of the state was its ability to impose taxes: "[t]he government by law obliges certain selected persons to become its debtors... This procedure is called levying a tax, and the persons thus forced into the position of debtors to the government must in theory seek out the holders of the tallies or other instrument acknowledging a debt due by the government." (Innes 1913, p. 398) Contrary to orthodox thinking, then, the desirability of the money-thing issued by the state was not determined by intrinsic value (even on the gold standard), but by the nominal value set by the state at its own pay offices. Nor was the government's money forced onto the public through legal tender laws. It is certainly true that governments often do adopt legal tender laws, but these are difficult to enforce and hence often ineffective. (Knapp 1924, p. 111) The power of government to impose a tax and to name what will be accepted in tax payment is sufficient, and trumps legal tender laws.

Once the state has created the unit of account and named what can be delivered to fulfill obligations to the state, it has generated the necessary pre-conditions for development of markets. ${ }^{9}$ (Ingham 2004a, p. 25) As Innes argued, credits and debts preceded markets, and indeed, created the need for markets. The primordial debt is the tax obligation, which then

8 In any case, coinage was a very late development that seems to have little to do with the search for a handy medium of exchange. See Cook (1958), Grierson (1977, 1979), Heinsohn and Steiger (1983, 1989), Kraay (1964), and Wray $(1998,2004)$.

9 Ingham argues that this only makes sense if markets are seen as multilateral exchange systems organized around price lists denominated in money of account. Markets are to be distinguished from bilateral barter exchange with myriad exchange ratios determined by subjective preferences. Thus - paradoxically neoclassical economics doesn"t possess a theory of markets - but mere exchange. 
creates the incentive for private credits and debts and then for markets. Indeed, evidence from early Babylonia suggests that early authorities set prices for each of the most important products and services - perhaps those accepted to meet obligations to the authorities. Once prices in money were established, it was a short technical leap to creation of markets. This stands orthodoxy on its head by reversing the order: first money and prices, then markets and moneythings (rather than barter-based markets and relative prices, and then numeraire money and nominal prices). The next step was the recognition by government that it could issue currency to purchase the mix it desired, then receive the same money thing in the tax payments by subjects/citizens. This would further the development of markets because those with tax liabilities but without the goods and services government wished to buy would have to produce for market to obtain the means of paying obligations to the state.

As Innes argues, the fundamental credit principle is that the issuer — whether household, firm, or government - must accept its own liabilities. Today only the sovereign government can impose liabilities on others. This puts it in a privileged position because it can create a demand for its own liabilities simply by requiring that taxpayers must deliver government liabilities in payment of taxes. It can also enact legal tender laws and legal reserve requirements to try to provide further privilege to treasury and central bank liabilities. Finally, the modern state is, of course, a very large entity — hence an important purchaser of output and source of incomewhich makes its liabilities ubiquitous. Still, if the state did not impose tax liabilities in its currency and require ultimate payments to itself in the form of its treasury and central bank liabilities, it is difficult to believe that its sheer size and its legal tender laws alone would be sufficient to guarantee its current spot at the top of the money hierarchy.

\subsection{Keynes}

While Keynes's General Theory presented the theory of aggregate effective demand that is now identified as "Keynesian theory," his earlier A Treatise on Money provided a more detailed treatment of his monetary theory. The first volume of that work presents definitions of money that would be used in his analysis; a brief examination of these provides insights into the view of money adopted by Keynes. Keynes was heavily influenced by both Knapp and Innes and indeed played a role in promoting their work. He reviewed the 1913 article by Innes in the Economic Journal, arguing that while further research might call into question some of the claims about the history of money made by Innes, Keynes said his understanding of money 
appeared sound. Apparently this led to a phase Keynes called his "Babylonian Madness," in which he made an intensive study of ancient monies and metrology, hence his emphasis on money as a measure (unit of account) — See Ingham (2013b, p. 6). This research seems to have heavily influenced his Treatise a decade later. Further, Keynes played a role in getting Knapp's book translated to English in 1924. There is some question about whether Keynes could read German, but he could certainly read the translation after 1924. His exposition in the Treatise closely follows that of Innes and Knapp.

According to Keynes, the "money of account" is the "primary concept" of a theory of money; the money of account "comes into existence along with Debts, which are contracts for deferred payment, and Price-Lists, which are offers of contracts for sale or purchase" (Keynes, 1930, p. 3). In turn, "Money itself, namely that by delivery of which debt-contracts and pricecontracts are discharged, and in the shape of which a store of General Purchasing Power is held, derives its character from its relationship to the Money-of-Account, since the debts and prices must first have been expressed in terms of the latter" (Ibid). He further clarifies the distinction between money and the money of account: "the money-of-account is the description or title and the money is the thing which answers to the description" (Ibid., 3-4).

Following Knapp, Keynes argued that the state determines what serves as the money of account as well as dictates what "thing" will be accepted as money.

The State, therefore, comes in first of all as the authority of law which enforces the payment of the thing which corresponds to the name or description in the contracts. But it comes in doubly when, in addition, it claims the right to determine and declare what thing corresponds to the name, and to vary its declaration from time to time - when, that is to say, it claims the right to re-edit the dictionary. This right is claimed by all modern states and has been so claimed for some four thousand years at least. (Keynes 1930, p. 4)

As an aside, the name, Modern Money Theory, comes from this statement. The "Age of Chartalist or State Money" had been reached, when the state "claimed the right not only to enforce the dictionary but also to write the dictionary" (Ibid., 5). Let us emphasize that Keynes believed the "Age of State Money" to have begun "at least" four thousand years ago. As such, the state theory of money would certainly apply to all the "modern" economies, including those living under the gold standard in the last century - even a gold-based "commodity" money is state money. We do not know whether money was used in pre-historic times, so its nature might 
have been different, but the age of modern money began with the rise of authorities at least four thousand years ago.

Privately issued debt — such as that issued by banks — might be accepted in settlement of transactions even if it is not declared by the government to be money; it can circulate "side by side" with "state money" (Ibid., 6). However, the state might "use its chartalist prerogative to declare that the [bank] debt itself is an acceptable discharge of a liability" (Ibid). Bank money then becomes a "Representative Money" (Ibid). "At the cost of not conforming entirely with current usage, I propose to include as State-Money not only money which is itself compulsory legal-tender, but also money which the State or the central bank undertakes to accept in payments to itself or to exchange for compulsory legal-tender money" (Ibid). In a footnote to this passage, he goes on: "Knapp accepts as "Money" - rightly I think - anything which the State undertakes to accept at its pay-offices, whether or not it is declared legal-tender between citizens” (Ibid., 6-7). Therefore, like Knapp, Keynes's analysis goes beyond legal tender laws to identify state "acceptation" as the key to determining what will serve as money.

Finally, state money may take any of three forms: "Commodity Money, Fiat Money and Managed Money, the last two being sub-species of Representative Money" (Ibid., p. 7). Commodity money is defined as "actual units of a particular freely-obtainable, nonmonopolized commodity which happens to have been chosen for the familiar purposes of money," or "warehouse warrants for actually existing units of the commodity" (Ibid). Fiat money is representative money "which is created and issued by the State, but is not convertible by law into anything other than itself, and has no fixed value in terms of an objective standard" (Ibid). This is distinguished from managed money, which "is similar to Fiat Money, except that the State undertakes to manage the conditions of its issue in such a way that, by convertibility or otherwise, it shall have a determinant value in terms of an objective standard" (Ibid., 8).

Managed money is, according to Keynes, the most general form of money, which can "degenerate into Commodity Money on the one side when the managing authority holds against it a hundred per cent of the objective standard, so that it is in effect a warehouse warrant, and into Fiat Money on the other side when it loses its objective standard" (Ibid). In other words, a full-bodied - say, one ounce - gold coin valued at one currency unit would qualify as commodity money, while a paper note, which is convertible to gold (and against which a fractional gold reserve is held), would qualify as managed money - even if the conversion rate is one currency unit per ounce of gold. Thus a gold standard system can be operated as either a 
commodity money or as a managed money. On the other hand, a representative money can take the form of either a managed money (a paper note convertible on demand to gold, or even to a foreign currency - for example a currency board system) or a fiat money (no promise to convert at a fixed exchange rate to precious metals or foreign exchange). Note that Keynes argued that even a gold standard, whether a commodity money system or a managed money system, operates as a state money system. In either case, the state can always "rewrite the dictionary," for example, by adopting a silver standard and a conversion rate (say, one ounce of gold for four ounces of silver).

State money can be held by banks, by the central bank, and by the public.

The State-Money held by the central bank constitutes its "reserve" against its deposits. These deposits we may term Central Bank-Money. It is convenient to assume that all the Central Bank-Money is held by the Member Banks - in so far as it may be held by the public, it may be on the same footing as State-Money or as Member Bank-Money, according to circumstances. This Central Bank-Money plus the state money held by the Member Banks makes up the Reserves of the Member Banks, which they, in turn, hold against their Deposits. These Deposits constitute the Member Bank-Money in the hands of the Public, and make up, together with the State-Money (and Central Bank-Money, if any) held by the Public, the aggregate of Current Money. (Keynes, 1930 pp. 9-10)

Any payments to the state using "Member Bank-Money" will cause member banks to lose "Central Bank-Money" or "State Money held by the Member Banks" - that is, reserves.

As Knapp recognized, "Member Bank-Money" is the primary "thing" answering to the "description" - money — used in private transactions (or, within the "private pay community"). When accepted in payment of taxes, it is also used in the "public pay community," but it is not "definitive" or valuta money from the perspective of member banks, because they must deliver reserves (mainly "Central Bank-Money”) whenever taxes are paid using "Member Bank-Money."

In summary, with the rise of the modern state, the money of account ("the description") is chosen by the state, which is free to choose that which will qualify as money ("the thing" that answers to the description). This goes beyond legal tender laws, which establish what can legally discharge contracts, to include that which the state accepts in payment at its "pay offices." The state is free to choose a system based on commodity money, fiat money or managed money. Even if it chooses a strict commodity system, the value of the money does not 
derive from the commodity accepted as money, "[f]or Chartalism begins when the State designates the objective standard which shall correspond to the money-of-account." (Keynes 1930, p. 11). "[M]oney is the measure of value, but to regard it as having value itself is a relic of the view that the value of money is regulated by the value of the substance of which it is made, and is like confusing a theatre ticket with the performance" (Keynes, 1983, p. 402). Once it is recognized that the state may "write the dictionary," it becomes obvious that the nominal value of a commodity (or managed) money cannot be derived from the value of the "objective standard"; it is then a small step to a "fiat money" with no "objective standard", for in all three cases, the state determines the nominal value of money. This is done when the state establishes what it will accept at public pay offices, as well as the nominal value of the thing accepted.

\section{MINSKY, LERNER AND INGHAM: LATER DEVELOPMENTS OF THE APPROACH}

\subsection{Minsky}

As discussed above, Keynes recognized that banks can normally increase loans to finance an increase of spending. ${ }^{10}$ Before Keynes, Schumpeter had developed a view of dynamic and innovative banks, in which credit expansion was the key to allow entrepreneurs to finance innovation. Indeed, credit was seen as "essentially the creation of purchasing power [by banks] for the purpose of transferring it to the entrepreneur" (Schumpeter, 1934, p. 107).

What is important to note is that if money supply responds to money demand, the "quantity of money" is not "exogenous" in the sense of being determined either through monetary policy (such as control by the central bank over bank reserves) or by the quantity of a precious metal reserve (as under a "commodity money" or "managed money" system). ${ }^{11}$ While the state defines money, it does not control the quantity. The state is able to control its initial emission of currency, but this is through fiscal policy rather than through monetary policy. That is, the quantity of currency created is determined by purchases of the state (including goods, services and assets purchased by the Treasury and the central bank); much of this currency will then be removed from circulation as taxes are paid. The rest ends up in desired hoards, or flows to banks to be accumulated as bank reserves. Monetary policy then drains excess reserves,

10 This is even clearer in his 1937 articles, after publication of The General Theory. See Keynes (1973). 11 Note that most "money" is credit money; here we are using the term "money" in its broad sense. 
removing them from member bank accounts, and replacing them with bonds voluntarily purchased. As Boulding (1950) had argued, fiscal policy has more to do with the quantity of money issued by the government, while monetary policy has to do with regulation of financial markets (most importantly, with determination of short-term interest rates).

Hyman Minsky presented a view of money that was based on the Chartalist approach. ${ }^{12}$ His approach emphasized the "endogeneity" of money, that is, the view that money is created during the normal, and important, processes of a capitalist economy — and is not created and “dropped by helicopters” (as in Milton Friedman's famous exogenous, helicopter money story). For the most part, bank money is created as banks "make loans." Further, Minsky borrowed from his original dissertation adviser, Schumpeter, the notion of profit-seeking innovations, and applied that to his view of banking and money creation.

Money is unique in that it is created in the act of financing by a bank and is destroyed as the commitments on debt instruments owned by banks are fulfilled. Because money is created and destroyed in the normal course of business, the amount outstanding is responsive to the demand for financing. (Minsky, 1986, p. 249)

A "loan" is nothing more than an agreement by a bank to make payments "now" on the basis of a promise of the borrower to "pay later." "Loans represent payments the bank made for business, households and governments in exchange for their promises to make payments to the bank at some future date" (Ibid., 230). ${ }^{13}$ (We won't go into it here but this view leads to Minsky's financial instability hypothesis: over the course of the cycle, margins of safety on lending decline, making the financial system more fragile and thus vulnerable to a crisis.)

All of this lending activity occurs on the balance sheets of banks; the "money" that is created by a bank is nothing more than a credit to another bank's balance sheet. ${ }^{14}$ According to Minsky, there is a pyramid of liabilities, with those of the central bank at the top. Bank liabilities are convertible on demand into central bank liabilities, which are used for interbank clearing (as well as for conversion of bank liabilities to "cash" held by the public, resulting in a net reserve drain).

12 In private conversation, Minsky acknowledged his intellectual debt to the Chartalists and especially to Knapp. 13 Note the similarity to Innes's view. "Debts and credits are perpetually trying to get into touch with one another, so that they may be written off against each other, and it is the business of the banker to bring them together ... There is thus a constant circulation of debts and credits through the medium of the banker who brings them together and clears them as the debts fall due. This is the whole business of banking as it was three thousand years before Christ, and as it is today" (Innes, 1913, pp. 402-3).

14 As the borrower spends the created money, a check drawn on the first bank is deposited with another. 
The payments banks make are to other banks, although they simultaneously charge the account of the customer. In the receiving bank, the payments are credited to a depositor's account.... For member banks of the Federal Reserve System, the interbank payments lead to deposits shifting from the account of one bank to the account of another at Federal Reserve banks. For nonmember banks, another bank-called a correspondent-intervenes, so that the transfer at the Federal Reserve banks are for the accounts of correspondents. (Minsky, 1986, pp. 230-1)

Thus "payments" among banks occur on the balance sheet of the Fed as banks use "Fed money" (reserves) to settle net debits from their accounts. "Whereas the public uses bank deposits as money, banks use Federal Reserve deposits as money. This is the fundamental hierarchical property of our money and banking system" (Ibid., 231). This is, of course, in the same hierarchical arrangement noted by Knapp (in his public and private pay communities) and by Keynes.

Banks are "special" in that they have the government back-stopping them. Not only does the central bank provide clearing services (in its own liability, reserves) but it also stands ready to act as lender of last resort as necessary to keep the payments system functioning by providing liquidity on demand. Further, most countries also have the treasury standing behind at least some bank deposits—demand deposits, usually—by providing deposit insurance. However, Minsky also insisted that banks do not have a monopoly on "money creation"; he always said that anyone can create money; the problem is to get it accepted. He used the analogy of a pyramid of liabilities, with the state's IOUs at the top (central bank and treasury), then bank IOUs in the middle, and household and firm liabilities at the bottom. The most liquid and acceptable IOUs are at the top, with acceptability declining as we move down the pyramid. Of course, this is a generic ordering that can vary depending on particular circumstances. For example, it is possible that a foreign currency - say, the US dollar - is even more acceptable than the national government's currency; and it is conceivable that the IOUs of a nonfinancial corporation could, in some cases, be more acceptable than those of banks.

In an argument very similar to Knapp's Chartalist view, Minsky explained that people accept bank money in part because they can use it to meet their own commitments to banks. "Demand deposits have exchange value because a multitude of debtors to banks have outstanding debts that call for the payment of demand deposits to banks. These debtors will work and sell goods or financial instruments to get demand deposits" (Ibid., 231). In other 
words, according to Minsky, bank money has (nominal) value precisely because it can be used to retire debts to banks - it is, so to speak, accepted at "bank pay offices." The "borrower" retires his/her promise to the bank by delivering bank liabilities at the future date, and the need for bank liabilities to retire one's own liabilities to banks leads one to accept bank liabilities in payment for goods and services delivered. Rather than focusing on money as a medium of exchange, this focus is on money as means of payment — to retire liabilities.

This led Minsky back to the Innes/Knapp recognition that taxes give value to the money issued by the government. ${ }^{15}$

In an economy where government debt is a major asset on the books of the deposit-issuing banks, the fact that taxes need to be paid gives value to the money of the economy... [T] he need to pay taxes means that people work and produce in order to get that in which taxes can be paid. (Ibid., 231)

And even though most taxes are paid by drawing down bank deposits, because of the hierarchical arrangement, Keynes and Minsky emphasize that banks can make these payments to government only by using central bank money, that is, by losing reserves.

\subsection{Lerner}

Following the primary Chartalist theme, ${ }^{16}$ Abba Lerner insisted that

[W] hatever may have been the history of gold, at the present time, in a normally wellworking economy, money is a creature of the state. Its general acceptability, which is its allimportant attribute, stands or falls by its acceptability by the state. (Lerner, 1947, p. 313)

Just how does the state demonstrate acceptability? Lerner echoes Innes:

The modern state can make anything it chooses generally acceptable as money... It is true that a simple declaration that such and such is money will not do, even if backed by the most convincing constitutional evidence of the state's absolute sovereignty. But if the state is willing to accept the proposed money in payment of taxes and other obligations to itself the trick is done. Everyone who has obligations to the state will be willing to accept the pieces of paper with which he can settle the obligations, and all other people will be willing to accept

15 This has been recognized by Goodhart, who argues that "The use of such state-issued fiat currency was supported by several factors. First the state levies taxes and can insist that these be paid in state-issued money. This ensures that such fiat currency will have some value" (Goodhart, 1989, p. 36). Similarly, James Tobin argues that "By its willingness to accept a designated asset in settlement of taxes and other obligations, the government makes that asset acceptable to any who have such obligations, and in turn to others who have obligations to them, and so on" (Tobin, 1998, p. 27).

16 However, I know of no evidence that Lerner was aware of the work of Innes. 
these pieces of paper because they know that the taxpayers, etc., will accept them in turn. (Ibid.)

Like Innes and Keynes, Lerner argues that even if it has not always been the case, it surely is now true that the state writes the "description" of money when it denominates the tax liability in a money of account, and defines the "thing" that "answers to the description" when it decides what will be accepted at public pay offices. The "thing" which answers to the "description" is widely accepted, not because of sovereignty alone, not because of legal tender laws and not because it might have (or have had) gold backing, but because the state has the power to impose and enforce tax liabilities and because it has the right to choose "that which is necessary to pay taxes." As Lerner said, "Cigarette money and foreign money can come into wide use only when the normal money and the economy in general is in a state of chaos" (Lerner, 1947, p. 313). One might only add that when the state is in crisis and loses legitimacy, and in particular loses its power to impose and enforce tax liabilities, "normal money" will be in a "state of chaos," leading, for example, to use of foreign currencies in private domestic transactions. In most cases, it is state money which is used, and state money is that which the state accepts in payment of taxes.

Perhaps the more significant and contentious point concerns the implication of the state money approach for government budgetary issues. Lerner's $(1943,1947)$ "money as a creature of the state" approach leads logically to his "functional finance" view of state budgeting. Because the state spends by emitting its own liability, it does not need tax revenue or the proceeds from borrowing in order to spend.

Thus, Lerner's first principle of functional finance is that the state should increase taxes only if the public's income were too high (threatening inflation). His second principle is that the state should "borrow" (sell bonds) only if "it is desirable that the public should have less money and more government bonds." (Lerner 1943, p. 40) We will return to these points in the conclusion when we briefly detail the policy implications of MMT. However, the important point here is that Lerner argued that government finance should be functional, that is, formulated with a view to accomplishing the government's goals, including full employment and low inflation. He opposed this to the notion of sound finance, which is the view that the government's budget should be set to "balance" tax revenues against spending. Few supporters of sound finance argue for a continuously balanced national government budget. They accept 
deficits in recession but typically argue that these should be largely offset by surpluses in expansions. Some allow for deficits so long as these are undertaken for "investment" type purposes (this would be analogous to a private firm's separation of its current account from its capital account, with its current account in balance but a deficit allowed on its capital account). Lerner insisted that all versions of sound finance should not be applied to the national government that issues its own currency. Government should never raise taxes to reduce its budget deficit, but rather should increase taxes only if inflation threatens. And, in line with the second principle, government should never sell bonds (what most economists call "borrowing") simply because it finds itself with a budget deficit. Rather, bonds should be sold only if there is downward pressure on interest rates, pushing them below the central bank's target rate.

\subsection{Ingham}

Geoffrey Ingham has made important contributions bringing a sociologist's interest in the ontology of money to reexamine the nature of money. Like Goodhart (1998), he contrasts the neoclassical commodity money approach with the heterodox State money approach. He has also linked the evolution of credit money to the development of capitalism. This section will briefly outline these two topics.

As Ingham argues, orthodoxy has little interest in the ontology of money, taking a "money is what money does" stance, focusing on its three or four main functions. He insists, however, that

money should not be seen simply as a useful instrument; it has a dual nature. Money does not merely have "functions" - that is to say, beneficial consequences for individuals and the social and economic system. In Mann's terminology, money is not only "infrastructural" power, it is also "despotic" power (Mann 1986). Money expands human society's capacity to get things done, as Keynesian economics emphasizes; but this power can be appropriated by particular interests. (Ingham 2004a, p. 20)

Here, he's not merely referring to the obvious fact that holding money gives one economic power, but "the actual process of the production of money in its different forms is inherently a source of power. For example, modern capitalist money is bank credit-money that is produced on the basis of credit ratings that reinforce and increase existing levels of inequality by imposing differential interest rates.... money is a weapon in the struggle for economic existence." (Ibid.) 
Following Keynes, Ingham claims that:

an abstract money of account is logically anterior to money's forms and functions; it provides all the most important advantages that are attributed to money in general and a medium of exchange in particular. Money of account makes possible prices and debt contracts, which are all that are required for extensive multilateral exchange to take place. Money accounting, with or without an actual "money stuff," is the means by which modern market exchange is made possible - that is, of producing action at both spatial and temporal distance. In this conception money is abstract - but an abstraction from what? (Ingham 2004a, pp. 21-22)

He goes on to argue that the orthodox answer to that question is doubly paradoxical. Since it adopts a commodity money view, it wants to argue that money's value is determined in the usual neoclassical way: scarce supply meets the demand for money determined by subjective preferences. Yet, because modern orthodoxy recognizes that money actually consists of some scarce commodity with an intrinsic exchange value, the scarcity of supply must be imposedgenerally through control by authorities. At the same time, money is supposed to be neutral (aside from some short term non-neutralities resulting from imperfections), determining only irrelevant nominal prices and not the all-important relative prices that come out of the higgling and haggling of the market. It is for that reason that many rigorous neoclassical models simply leave money out of the analysis altogether. ${ }^{17}$

Again, Ingham follows the heterodox approach, where money's value is always abstract and nominal:

[T] he strands of the alternative conceptions of money that Schumpeter identified are drawn together in a discussion of money as "abstract value" and a "credit", or "claim". Attention is drawn to the close relationship of these theories to the state, or "chartalist" theory of money. Together, they provide the foundations for a non-market theory of money that Keynes referred to as the "underworld" of monetary analysis. This account aims to make more explicit what I take to be the inherently sociological nature of these "nominalist", "credit", and "state" theories of money. (Ingham 2004a, p. 24)

....[B]y a "sociology of money" I intend more than the self-evident assertion that money is produced socially, is accepted by convention, is underpinned by trust, has definite social and cultural consequences and so on. Rather, I argue that money is itself a social relation; that is

17 The neoclassical economic assumption that myriad barter exchanges ("higgling and haggling") will produce a commodity with a stable exchange rate with all others - that becomes money - is highly improbable that myriad. A hundred commodities could yield 4950 exchange rates (Ingham 2004 b, 25; Ingham 2013b 122). This would literally "boggle the minds" of our higglers and hagglers who would try to come up with a single commodity in which to price all other commodities. 
to say, money is "claim" or "credit" that is constituted by social relations that exist independently of the production and exchange of commodities. (Ibid., 25)

Regardless of any form it might take, money is essentially a provisional "promise" to pay whose "moneyness", as an "institutional fact" [...] is assigned by a description conferred by an abstract money of account. Money is a social relation of credit and debt denominated in a money of account. In the most basic sense, the possessor of money is owed goods. But money also represents a claim or credit against the issuer - monarch, state, bank and so on. Money has to be "issued". And something can only be issued as money, if it is capable of cancelling any debt incurred by the issuer. (Ibid., 25)

He refers to Knapp's argument that the state issues money in payment, promising to accept it in payment of taxes. It must be denominated in an abstract money of account, for otherwise it would not be transferable. A debt denominated in a commodity — say, pigs — could not circulate. Similarly, the bank issues notes which it promises to accept in repayment of loans - and these too must be denominated in an abstract money of account. Power necessarily resides in these credit/debt relations.

Ingham draws on Georg Simmel, pointing to the "essential characteristic of money as abstract value in terms of itself (money proper answering the description given by money of account). Money is "one of those normative ideas that obey the norms that they themselves represent." (Ingham 2013b p. 124) As Simmel put it, "To establish a proportion between two quantities, not by direct comparison but in terms of the fact that each of them relates to a third quantity and that these relations are unequal or equal is one of society's great accomplishments.” (Simmel 1978[1907] p. 122, quoted by Ingham 2013b p. 124) Market exchange cannot be based on comparison of bilateral relative prices, but rather needs an external referent, a nominal measure of value. Further the medium of exchange cannot be a commodity with a relative price but must be measured in the "socially constructed standardized measure of abstract value.” (Ingham 2013b p. 124)

[M] dia of exchange cannot evolve spontaneously through repeated barter exchanges into monetary systems in which debts are expressed in units of abstract value and settled by means of final payment/settlement of debts that represent quantities of the same value. (Ingham 2013b, p. 126)

Ingham, suggests that in order to understand the historical distinctiveness of capitalism, the admittedly confused distinction between money and credit should not be entirely abandoned. 
According to Ingham, saying that all money is essentially a credit is not the same as saying that all credit is money:

I have argued elsewhere that whilst all money is credit, not all credit is money (Ingham 2004b). In this I have merely followed Simmel's clear well-established and essentially sociological distinction between bilateral and multilateral, or "private" and "public", relationships. In a monetary system: "the pivotal point in the interaction between the two parties recedes from the direct line of contact between them, and moves to the relationship which each of them ... has with the economic community that accepts money. This is the core of the truth that money is only a claim on society. Money appears so the speak as a bill of exchange from which the drawee is lacking ... It has been argued against this ... that credit creates a liability, whereas metallic money payment liquidates any liability; but this argument overlooks the fact [that] ... [t] he liquidation of every private obligation by money means that the community now assumes this obligation to the creditor." (Ingham 2013b pp.128, quote from Simmel 1978 [1907]: 177)

In other words, he argues that not all credits are a final means of payment, or settlement. For Ingham, the question hinges not on the form of money or credit - as in most discussions within orthodox economic analysis - but on the social relations of monetary production. These relations comprise the monetary space and the hierarchy of credibility and acceptability by which money is constituted. The test of "moneyness" depends on the satisfaction of both of two conditions. First, the claim or credit is denominated in an abstract money of account. Monetary space is a sovereign space in which economic transactions (debts and prices) are denominated in a money of account. Second, the degree of moneyness is determined by the position of the claim or credit in the hierarchy of acceptability. Money is that which constitutes the means of final payment throughout the entire space defined by the money of account.

In monetary systems, it is the obligation of the issuer of money - bank, treasury, etc - to promise to accept that which it has issued as the final settlement of any debt owed to it. Furthermore, it is a condition of monetary systems system that offers of goods are priced in the money of account. Thus there are two crucially linked senses in which money is a creditdebt relation: for the issuer and for the holder of money. ... Monetary relations involve two simultaneous relations: between the contracting agents and between these and the issuer of money. This triangular relation involves impersonal trust which enables transactions between strangers. In modern monetary systems there are several interconnected "triangles" of impersonal trust which link a hierarchy of intermediaries - credit card issuers, banks, central banks, states. (Ingham 2013b p. 128) 
While it is commonplace to argue that our credit system relies on "trust," following Simmel, Ingham nicely distinguishes personal trust from impersonal trust, which is necessary for markets. Holders of money have a general claim against society's productive capacity.

Money in the sense of a fixed quantum of abstract value denominated in a unit of account (that is to say, measured by itself) cannot exist as such without the existence of reciprocal actual and potential debts, denominated in the same money of account, waiting to be discharged. In other words, money can only be conceived of as a monetary system - not merely as the most exchangeable commodity.... Again, it is a question of the different levels or layers of social reality. It is true to say that no particular individual possessor of money is owed goods by any particular individual. But in general if possessors of goods cease to offer them for sale at a money price then the monetary system has in effect ceased to exist as of course frequently occurs when there is a loss of impersonal trust in the issuer of money. (Ingham 2013b p. 129)

In Ingham's view, a further important consideration is the process by which money is produced. As Innes had observed, members of a giro (created for the settlement of debt) cleared accounts without use of coin as early as Babylonian banking. However, these credit relations did not involve the creation of new money. In contrast, the capitalist monetary system's distinctiveness is that it contains a social mechanism by which privately contracted credit relations are routinely "monetized" by the linkages between the state and its creditors, the central bank, and the banking system.

[C]apitalism's distinctive structural characteristics are to be found in its social relations for the production of "credit-money." Capitalism is founded on the social mechanism whereby private debts are "monetized" in the banking system. Here the act of lending creates deposits of money. This did not occur in the so-called banks of the ancient and classical worlds. (Ingham 2004a p. 26)

Capitalist "credit money" was the result of the hybridization of the private mercantile credit instruments ("near money" in today's lexicon) with the sovereign's coinage, or public credits: "a stable and uniform measure of value can only be produced by an authority outside the sphere of exchange -usually, but not necessarily a state.” (Ingham 2013a, p. 132)

In conclusion, Ingham argues, the essential element is the construction of myriad private credit relations into a hierarchy of payments headed by the central or public bank which enables lending to create new deposits of money - that is, the socially valid abstract value that constitutes the means of final payment. Returning to that notion of a hierarchy, or pyramid, of 
monies with the state at the top, Ingham argues "There is, as Amato and Fantacci succinctly observe, 'no liquidity without a lender of last resort, no lender of last resort without an irredeemable consolidated debt, and no irredeemable debt without an immortal state"" (Amato and Fantacci 2012: 236; quoted in Ingham 2013b, p. 23). This nicely ties together credit and state approaches to money to identify what is special about capitalism: "The uniqueness of the capitalist era lies in the successful hybridisation of chronically fragile and unstable private mercantile credit networks with public currency based on the increasing security of stable states' metallic standards.” (Ingham 2013b, pp. 139-140)

\section{CONCLUSIONS: POLICY IMPLICATIONS OF MMT}

We will conclude by briefly addressing implications of this alternative approach to money for our understanding of monetary and fiscal policy — both as practiced and for the policy space available to a government that issues its own currency.

It is important to note how the state money approach conflicts with the conventional "government budget constraint" (GBC) notion, according to which state spending must be "financed" by tax revenues, borrowing, or "printing money." In reality, the GBC is nothing but an ex post identity that conflates the state's financial situation with that of a household. The state money approach insists that so long as state liabilities are demanded, they can be supplied by the state (central bank plus treasury) in its spending (and lending). There is no limited supply of either private or state IOUs - so long as either is willing to issue IOUs, they can be supplied. The problem, as Minsky said, is to get them accepted. In other words, the limit is on the demand side.

One of the factors that determines willingness to accept IOUs is the perception of credit worthiness. Banks and other financial institutions specialize in underwriting - the process of identifying credit-worthy borrowers. There is no physical constraint on bank ability to create demand deposits as they make loans (holding the IOUs of borrowers); the main constraint is the ability to locate good borrowers. In addition banking regulations and supervisors (as well as prudent managers) impose capital constraints and other kinds of quantitative as well as quantitative restraints. Another factor limiting acceptance of IOUs is the perception of liquidity; even if there were little doubt about credit worthiness, the liquidity of debt matters because the 
holder might need "cash" before payment comes due. We will not go further into the business of banking.

When it comes to the state's ability to issue IOU (whether currency, central bank reserves, or treasury securities), what matters again is acceptability on the demand side. As a sovereign power, however, the state can mandate at least some demand for its IOUs by imposing obligations that must be paid in the state's currency. Beyond that, by sitting at the apex of the "money pyramid," the state's IOUs are demanded for clearing purposes and also for reserves of the most liquid assets. We conclude, again, that the constraint on the state's ability to issue its IOUs comes mostly from the demand side. However, the state can also impose constraints on its issue: it has a budgetary process that necessarily limits its spending, and it can go further by imposing a debt limit (as the US has done). Of course, some want to go further, by imposing a balanced budget requirement (or Maastricht-like debt and deficit ratios). Still others want to make a sovereign currency system operate more like the imagined commodity money system, by requiring conversion on demand to gold or to foreign currency. Note that such constraints are necessarily politically imposed - they do not come about "naturally" due to a "commodity nature" of money.

Most economists recognize that there is no natural limit to a sovereign government's ability to spend by issuing currency — something that is often equated to "printing money to finance spending." However, it is believed that this is the least preferred method of financing spending. It is said to be safest to use tax revenue; the second best method is to borrow by issuing treasury securities. Both of these impose some market discipline - the first by limiting government spending to its "income" and the second by limiting government's deficits to what markets are willing to finance by "lending" to government. Following Lerner, the state money approach rejects all such arguments. It is best to think of currency creation, tax receipts, and bond sales as different parts of the process of government spending, rather than as optional ways to "finance" government spending. To put it very briefly, the spending logically comes first before government obtains tax revenue or sells bonds. If the government receives in tax payments its own IOUs, it must first supply them before taxes can be paid. And if bond purchasers must use the government's IOUs to pay for the bonds they buy, then government must have spent (or lent) its IOUs before it sold the bonds.

As Lerner argued, the functional purpose of government bond sales is not to borrow reserves (the government's own IOU), but to offer an interest-earning alternative to undesired 
reserves that would otherwise drive the overnight rate (bank rate or federal funds rate) toward zero. While it might appear that the bond sales "finance" the treasury spending, in reality, bond sales are taken after the spending takes place, and are undertaken to mop up the excess reserves that push overnight rates below target. We, thus, return to the second principle of functional finance: bonds should be sold only if the private sector holds more HPM than desired, a situation that is manifested by overnight rates falling below target. Hence, the functional finance approach insists that reserves are nondiscretionary. Indeed, the second principle of functional finance can be seen as implying that bond sales are undertaken only to drain excess reserves. Thus, bond sales, even by the treasury, are nondiscretionary and permit the central bank to hit interest rate targets.

Note that if the central bank (CB) paid interest on excess reserves, the treasury would never need to sell bonds because the overnight interest rate could never fall below the rate paid by the $\mathrm{CB}$ on excess reserves. Note also that in spite of the widespread belief that government deficits push up interest rates, they actually reduce the overnight rate to zero unless the treasury and $\mathrm{CB}$ coordinate efforts to drain the resulting excess reserves. (For proof, for two decades the overnight interest rate in Japan has been kept at zero, in spite of government deficits that reached 8 percent of GDP, merely by keeping some excess reserves in the banking system.) On the other hand, budget surpluses drain reserves, causing a shortage that drives up the overnight rate unless the $\mathrm{CB}$ and treasury buy and/or retire government debt. Orthodoxy has got the interest rate effects of government budgets exactly backwards.

In the US, the Fed is, like the Treasury, ultimately a "creature of Congress," and notwithstanding various claims about the desirability of the independence of the central bank, this is a typical arrangement in most developed nations. Leaving aside the logical impossibility of central bank "independence" from its treasury (since hitting overnight rate targets requires cooperation between treasury and central bank), the law-making body can direct its central bank to accommodate the treasury's spending as necessary. (Indeed, if it did not, treasury checks could "bounce.") While a government budget constraint holds ex post (government spending would be "financed" by issue of central bank liabilities in the sense that increased treasury spending would lead to increased credits of reserves to the banking system), it is not an operational constraint on treasury spending. In practice, as soon as the central bank meets all the demand for bank reserves by crediting reserves as the treasury spends, additional treasury 
spending places downward pressure on the overnight rate, forcing bond sales (by the central bank and/or the treasury) to drain excess reserves and keep overnight rates on target.

By integrating the state and credit theories of money, we are able to understand the general principle that all issuers of IOUs must "redeem" them by accepting them in payment. The special principle that applies to the sovereign state is that it can ensure at least some acceptability for its IOUs by imposing taxes and other monetary obligations. So long as the state only promises to "redeem" its IOUs in payments to itself (that is, it does not promise conversion at a fixed rate to precious metal or foreign currency), it can never be forced into involuntary default. This is part of the reason that states are able to stand at the top of the pyramid. The limit on state spending is not arbitrary deficit or debt ratios but rather real resources offered for sale for the state's currency. In other words, the main problem with excessive spending by the state is inflation, not risk of default and insolvency. 


\section{REFERENCES}

Bell, S., 2000. Do taxes and bonds finance government spending? Journal of Economic Issues. 34: pp. 603-620.

Boulding, K., 1950. A Reconstruction of Economics, New York: John Wiley \& Sons.

Cook, R.M., 1958. "Speculation on the Origins of Coinage.” Historia, 7, pp. 257-62.

Crawford, M., 1970. "Money and Exchange in the Roman World.” Journal of Roman Studies, 60, pp. $40-48$.

Goodhart, C.A.E., 1989. "Money, Information and Uncertainty” Cambridge, MA: The MIT Press.

1998. "Two concepts of money: implications for the analysis of optimal currency areas." European Journal of Political Economy. 14: pp. 407-432.

Grierson, P., 1977. "The Origins of Money.” London: The Athlone Press. , 1975. "Numismatics." London: Oxford University Press.

, 1979. "Dark Age Numismatics," London: Variorum Reprints.

Ingham, G., 2000. "Babylonian Madness: On the Historical and Sociological Origins of Money.” In John Smithin (ed.) What Is Money. London \& New York: Routledge.

, 2004a) "The Nature of Money," Economic Sociology: European electronic newsletter, Vol 5 (2), January 2004, pp. 18-28.

, 2004b. "The Nature of Money," Cambridge: Polity

, 2004c. "The emergence of capitalist credit money" in L. Randall Wray (ed) Credit and State Theories of Money, Cheltenham: Edward Elgar.

, 2013a. "O sacred hunger of pernicious gold! What bands of faith can impious lucre hold?” European Journal of Sociology, Vol 54, (1), April, pp. 127-146.

, 2013b. "Revisiting the Credit Theory of Money and Trust," in J. Pixley (ed) (2013).

New Perspectives on Emotions in Finance, London: Routledge, 121-139.

Innes, A. M.,1913. "What is money? Banking Law Journal. May: pp. 377-408. Republished as "What is Money?"; in L. Randall Wray (ed) 2004, Credit and State Theories of Money, Cheltenham: Edward Elgar. 
,1914. The Credit Theory of Money, Banking Law Journal, January: pp. 151-168.

Republished as "The credit theory of money" in L. Randall Wray (ed) 2004, Credit and State Theories of Money, Cheltenham: Edward Elgar.

, 1932. "Martyrdom in Our Times: Two Essays on Prisons and Punishment": London, Williams \& Norgate, Ltd.

Keynes, J.M., [1930] 1976. “A Treatise on Money," Volumes I and II, New York: Harcourt, Brace \& Company.

, (1964). “The General Theory,” New York: Harcourt-Brace-Jovanovich.

, (1972). "The Collected Writings of John Maynard Keynes, Volume IX: Essays in Persuasion," edited by Donald Moggridge, London and Basingstoke: Macmillan/St. Martin"s Press.

, 1973. "The Collected Writings of John Maynard Keynes, Volume XIV: The General Theory and After: Part II Defence and Development," edited by Donald Moggridge, London and Basingstoke: Macmillan/Cambridge University Press.

1980. "The Collected Writings of John Maynard Keynes, Volume XXVII: Activities 1940-46, Shaping the Post-war World: Employment and Commodities," edited by Donald Moggridge, London and Basingstoke: Macmillan/Cambridge University Press. , 1982. “The Collected Writings of John Maynard Keynes, Volume XXVIII," edited by Donald Moggridge, London and Basingstoke: Macmillan/Cambridge University Press.

, 1983. "The Collected Writings of John Maynard Keynes, Volume XI: Economic Articles and Correspondence, Academic," edited by Donald Moggridge, London and Basingstoke: Macmillan/Cambridge University Press.

Knapp, G.F., [1924]1973. “The State Theory of Money,” Clifton, NY: Augustus M. Kelley.

Lerner, A.,1943. "Functional Finance and the Federal Debt," Social Research, vol. 10, pp. 3851.

, 1947. "Money as a Creature of the State," American Economic Review, 37(2), May, pp. $312-17$.

, 1961. “The Burden of the Debt," Review of Economics and Statistics, 43, pp. 139-41.

Mann, M., 1986. “The Sources of Social Power.” Cambridge: Cambridge University Press.

Minsky, H.P., 1986. “Stabilizing an Unstable Economy,” New Haven, CT: Yale University Press.

Moore, B.J., 1988. "Horizontalists and Verticalists: The Macroeconomics of Credit Money," Cambridge: Cambridge University Press. 
Mosler, W., 1995. "Soft Currency Economics, 3rd edition.” West Palm Beach, FL (selfpublished). Http: Iwww.warrenmosler.com.

Schumpeter, J.A., 1934. "The Theory of Economic Development: An Inquiry into Profits, Capital, Credit, Interest and the Business Cycle." Cambridge, MA: Harvard University Press.

Simmel Georg, 1978 [1907]. The Philosophy of Money (London, Routledge).

Tobin, J., 1987. "Essays in Economics," Volume 1: Macroeconomics, Cambridge, MA: The MIT Press. , 1998. “Money, Credit, and Capital,” Boston, MA: Irwin McGraw-Hill.

Wray, L. R., 1990. "Money and Credit in Capitalist Economies: The Endogenous Money Approach,” Aldershot, UK and Brookfield, US: Edward Elgar. ed., 2004. "Credit and State Theories of Money." (Cheltenham, Edward Elgar). , 1998. "Understanding Modern Money." (Cheltenham, Edward Elgar). ,2012. "Modern Money Theory: A Primer on macroeconomics for sovereign monetary systems," Palgrave. 